\title{
Rural Women empowerment through Micro-entrepreneurship development: Issues and prospects - a Review
}

\author{
Geetha. N \\ B.E., M.Tech., M.B.A.,M.Phil., Principal \&Managing Trustee, Sri Raghavendra Industrial training Institute, \\ Suwarna Nagaraju Educational Trust, Bangalore-79 Research Scholar (Jain University, Bangalore)
}

\begin{abstract}
A nation can only be developed if its women are given ample opportunities. Developing entrepreneurship among women will be the right approach for women empowerment. Empowerment of rural women has emerged as an important issue these days and is of paramount importance to the economists, political thinkers, social scientists and economic reformers. Women constitute $90 \%$ of total marginal workers of the country. Rural women who are engaged in agriculture form $78 \%$ of all women in regular work. Micro entrepreneurship among rural women is considered to be the institutional innovation that fosters empowerment of economically and socially deprived women which leads to development of family and community.

Keywords: Rural women, Empowerment, Micro entrepreneurship.
\end{abstract}

\section{Introduction:}

Women's empowerment is a new phrase in the vocabulary of gender literature. In general sense, it refers to empowering women to be self dependent by providing them access to all the freedoms and opportunities, which they were denied in the past only because of their being women.

In specific sense, women empowerment refers to enhancing their position in the power structure of the society.

Empowerment of women has five components:

- Women's sense of self worth.

- Their right to have access to opportunities and resources.

- Their right to have the power to control their own lives both within and outside the home.

- Their ability to have influence the direction of social change to create a more just social and economic order, nationally and internationally.

In today's competitive world, there are various ways by which women gets themselves empowered. The entrepreneurship of women is considered to be an effective instrument to the economic development and empowerment of women.

According to the census of India 2011, the population of India is more than 1.21 billion and out of it $72.20 \%$ population belongs to the rural area. Women constitute nearly $50 \%$ of population, perform two thirds of the work and produce $50 \%$ of food commodities consumed by the country. They earn one third of remuneration and own $10 \%$ of the property or wealth of the country. Women are regarded as the "better half" of the society and at par with the men. But in reality our society is still a male dominated and women are not treated as equal partners both inside and outside the four walls of the house. In fact they are treated as weak and independent on men. As such Indian women enjoy an unfavorable status in society.

Especially rural women in India, constitute $77 \%$ of female population, women play a vital role in farm and home system, they share a abundant responsibility and perform a wide range of duties in running the family, maintaining the house hold activities like rearing, feeding and attending to farm labor, tending domestic animals and possess skills and indigenous knowledge. Her direct and indirect contribution at the farm and home level along with livestock management operation has not only helped to save their assets but also led to increase the family income.

They were also engaged in starting individual or collective income generation programme with the help of self help groups. This will not only generate income for them but also improve decision-making capabilities that led to overall empowerment.

Entrepreneurship development of rural women through self help groups:

Women comprise half of human resources they have been identified as key agent of sustainable development. The contribution of women and their role in the family as well as in the economic development and social transformation are essential. Women constitute $90 \%$ of total marginal workers of the country. Rural women who are engaged in agriculture from $78 \%$ of all women in regular work. 
Micro-credit is promoting the small scale business enterprise and its major aim is to alleviate poverty by income generating activities among rural women, for achieving self sufficiency. The micro entrepreneurship also strengthens women and removes gender inequalities. Self help groups credit mechanism helps the members to involve in other community development activities.

The rural women are engaged in small scale entrepreneurship programs with the help of self help groups, where they were economically empowered, attaining good status in family and community. All self groups are promoting micro-enterprise through micro-credit intervention, that is the delivery of micro finance to the poor is smooth, effective and less expensive.

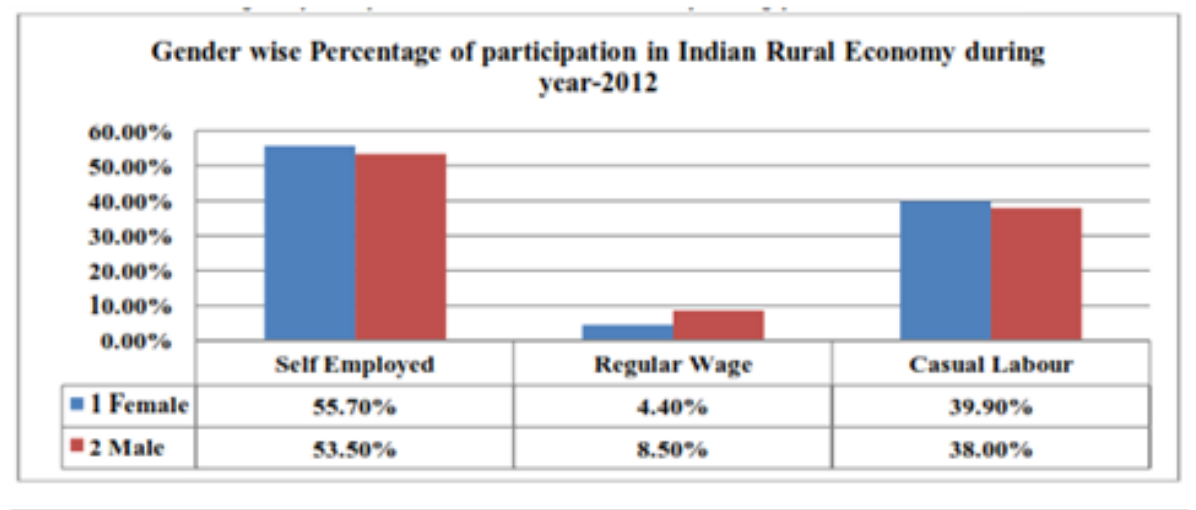

As per above graphical representation $55.70 \%$, rural women are self employed while the ratio of male is only $53.50 \%, 4.40 \%$ rural women are engaged in regular wages while males are $8.50 \%$ and casual labor comprises of $39.90 \%$ of women and $38 \%$ of men in rural economy of India. The result it makes us clear that interest of rural women is being increased towards the entrepreneurship in India.

\section{Scope of Micro enterprise development:}

Scope of micro enterprise depends on number of factors from land holdings, subsidiary occupations, agro climate conditions, political and socio-personal characteristics and family member of the rural women. It also differs from place to place.

Generally micro enterprise development is classified into 3 major heads:

1) Agriculture and allied agriculture activities like cultivating to organic vegetables, food grains, seasonal fruits, flowers, oil seeds and seed production besides mushroom growing and bee keeping.

2) Live stock management activities like dairy farming, poultry farm, domestic animals, feed production and production of dung cake by animal waste.

3) House hold based operations like knitting, stitching, weaving, embroidery, bakery flour milling, petty shops, food preparation and preservation.

\section{Role of micro-entrepreneurship in rural area:}

Empowering women especially in rural areas is a great challenge and micro-enterprises in rural area can help meet these challenges. The role of Micro-entrepreneurship is not only to enhance national productivity, generate employment but also to develop economic independence, personal and social capabilities like boosting self confidence, increasing awareness through social interaction; sense of achievement also improves leadership qualities and decision making.

In totality, the economic empowerment of rural women through micro-entrepreneurship has led to empowerment of women and contributed much to the development of nation.

\section{Conclusion}

No economy can sustain itself without participation of all those who are responsible and involved in its working, government has devised many programs to empower rural women in various avenues. Rural women can play an significant role by their effectual and competent involvement in entrepreneurial activities. They have basic indigenous knowledge, skill and potential and resources to establish and manage enterprise.

Micro enterprise is an effective instrument of social and economic development to generate employment for a number of people within their own social system and is a best tool for rural women as it adds to the family income. Now, the need of the hour is to equip them with knowledge regarding accessibility to loans, various funding agencies, procedure regarding certification, awareness of various government welfare 
programmes, technical skills and support from family, government and other non-government organizations. More over formation and strengthening of rural women entrepreneurs' network must be encouraged to motivate other women to take up entrepreneurship ventures.

Empowerment would not hold any meaning unless they are made strong, alert and aware of their equal status in the society particularly in rural areas. The need of hour is to improve female literacy as education holds the key to development of women in rural India.

\section{References:}

[1]. Business Today, September 18,2011. " The most powerful women in Indian Business".

[2]. Gorald.P, “Attributes, motives and goals to encourage women to start business," Quarterly Journal of business, No.44 pp.267-295, 2007.

[3]. Prabha Singh (2009) “ Rural Women and Development of Entrepreneurship with special reference to Punjab" in Empowerment of Rural women in India, Kansihka publishers, New Delhi.

[4]. Pradeep Kumar Singh. (2011). "Rural Women Empowerment through Entrepreneurship". International Journal of Asian Social Science,1(2), pp 24-26.

[5]. Ram Naresh Thakur (2009) “Rural women empowerment in India” in Empowerment of Rural women in India Kanishka publishers, New Delhi.

[6]. Sahab Singh, (2013) “A case study on empowerment of rural women through Micro entrepreneurship development". Vol 9,issue 6, pp123-125.

[7]. Shobhana Nelasco \& Junofy Antorozarina (2009) " Rural women empowerment through Self groups" in empowerment of rural women in India , Kanishka publishers, New Delhi.

[8]. Winn, Joan,(2005), "Women entrepreneurs: Can we remove barriers?" International Entrepreneruship and Management Journal, 1(3), 381-397. 